\title{
Think Tanks and Political Influence. How Influencer Networks and the Specialization of Power Are Represented on Twitter
}

\section{Els 'think tanks' i la influència política. Com es representen les xarxes d'influenciadors i l'especialització del poder a Twitter}

\section{Evgeni Tchubykalo}

University of Westminster (UK)

Juan Luis Manfredi-Sánchez

Universidad de Castilla-La Mancha (Spain)

Juan Antonio Sánchez-Giménez

Head of Information Service and Data Analysis

Real Instituto Elcano (Spain)

Think tanks are institutions that position themselves ideologically close to the powers that be, connecting them with science and defending the interests of lobbyists, while still striking a balance in the common interest of society. In the new context of political communication, think tanks take advantage of emerging trends in communication strategies by embracing the dissemination capacity of social media. On the assumption that these social networking sites expedite the task of think tanks, we will illustrate how thinks tanks leverage their influence and impact all over the world for agenda-setting and discourse framing purposes. This empirical research, which relies on data collected on Twitter, analyses the global influence map
Els think tanks són institucions que ideològicament es posicionen prop del poder, connectant-lo amb el món científic i sempre buscant l'equilibri entre els interessos dels lobbyist $i$ l'interès general de la societat. En el context de la nova comunicació política, els think tanks aprofiten les tendències més actuals en matèria de comunicació i adopten estratègies de difusió en els mitjans de comunicació social. Tenint en compte que una bona estratègia a les xarxes socials facilita la seva tasca, volem exemplificar com els thinks tanks utilitzen la seva capacitat d'influència i impacte en tot el món per redissenyar les agendes polítiques contextualitzant els seus discursos. Aquesta investigació empírica, que es basa en dades recopilades a Twitter, analitza el 
by searching for practice patterns that could help us to gain further insights into the relationship processes of these agents in international relations and the political context.

Key words: Twitter, political influence, think tank, power, social network analysis mapa d'influència global mitjançant la recerca de patrons de comportament que podrien ajudar-nos a obtenir més informació sobre les relacions entre aquests actors de les relacions internacionals i el context polític en el qual desenvolupen la seva activitat.

Paraules clau: Twitter, influència políti$c a$, think tank, poder, anàlisi de xarxes socials, lobby.

$\mathrm{T}$ Think tanks are a growing area of study in media research, as knowledge institutions with recognized expertise in a particular domain. For McGann and Johnson (2005), think tanks are institutions devoted to the analysis of international networks and to public policy research, whose main goal is to influence the various actors involved in decision-making processes. In times of uncertainty, such expert domains claim to be policy-relevant and expression of power, for instance, by producing normative power (Diez, 2013). Drezner (2017) gravitates towards an industry of ideas, where the end goal is to close the gap between useful knowledge creation and the decision-making process, and the growing complexity of public affairs. Medvetz as defines think tanks as "organizational devices for gathering and assembling forms of authority conferred by the more established institutions of academics, politics, business and the media" (2008: 9-10). Rich completes the definition highlighting the influence of nonprofitmaking institutions on think tanks: "independent, non-interest-based, non-profit organizations that produce and principally rely on expertise and ideas to obtain support and to influence the policymaking process" (Rich, 2004: 11). That issue explains who is interested in financing ideas that create authority and why they began to proliferate all over the world, especially in the USA (McGann, 2019) where $28 \%$ of world's think tanks operate (Álvarez-Rivadulla, Markoff and Montecinos, 2010: 173).

By nature, they are instruments to influence public and private policies and decisions, to carry debates and to propose solutions to real-problems. Xifra and Ponsa (2009) traced how American think tanks adopted marketing strategies after World War II in order to transform ideas into products and services to be delivered. Weaver held the same approach, considering think tanks as "strong policy bent" institutions with "effort to influence current policy debate" (Weaver, 1989: 567).

Campbell and Pedersen (2014) point out the difficulties in comparing think tank activity in Europe and the United States, as the "knowledge regime" differs. 
For instance, while in the US, think tanks are moving away from political party structure; European political parties often use one or several think tanks as idea labs and outlets for partisan propositions (Baier and Bakvis, 2001). However, McGann and Weaver (2000) do identify ways in which Think Tank activity can be promoted. They are as follows: 1) basic research on public policy issues; 2) advice on the latest issues and challenges for the government; 3) assessment of government policy; 4) promotion of network creation and exchange of ideas; 5) provision of specialized personnel for political actors and 6) analysis and interpretation of events and policies for media.

Knowledge creation through applied research places think tanks somewhere in the middle ground between academia and political discussion. They are mediation spaces for academic, political, business, journalist and diplomat elites (Medvetz, 2012; Wallace, 1994). The supply of expert knowledge attracts decision-makers (Rich, 2004) because it simplifies research for that audience (Arin, 2014). The role of think tanks in international activities is understood within the "capturing political imagination" process of public policy creation (Stone, 1996).

Mapping think tank influences or the relations which are developed among them can show a better picture: the analysis defines the interactions among think tanks considering 1) nodes, 2) ties and exchanges and 3) interdependent patterns. Think tanks are considered "networks of professionals with recognized expertise and competence in a particular domain and an authoritative claim to policy-relevant knowledge" (Haas, 1992: 3). To figure out the influence, we considered Twitter as tool of presence and reference in the networked society. In order to understand social influence on Twitter it is necessary to focus on popularity and reputation, as social influence is a process of analyzing "how information spreads in the Twitter network" (García et al., 2017: 2).

Open presentation propositions of public policy are part of the communication strategies and influence which think tanks exert (Abelson, 1992; Abelson, 2002; Rich and Weaver, 2000; McDonald, 2014). This is why the presence of researchers has multiplied on the press through interviews, talk shows and other events related to the media. The media is "the most visible method think tanks pursue to attract exposure" (Abelson, 2002: 74). Ahmad (2008) explains that the Heritage Foundation and the Brookings Institution create their own audiovisual products ad hoc for this purpose.

Influence has become sophisticated. This has forced think tanks to revise their options within actions and initiatives intended to influence on the public sphere (Wiarda, 2015). Internet and social media have opened a new flood of research with conclusive results. In the US, conservative think tanks use social media widely to promote their goals in different platforms such as Facebook, Twitter and Instagram, as well as YouTube (Chafuen, 2019). In Latin America, more than $80 \%$ of think tanks do regularly publish original content into different platforms (Castillo and Trujillo, 2012). In the United Kingdom, Lewis and Cushion (2017) indicate that right-wing think tank received better cover than left oriented institutions, while Anstead and Chadwick conclude that think tanks' authority is being translated to social media (Anstead and Chadwick, 2018). Social media, 
and above all, Twitter, represent the epitome of think tank influence transformation (Manfredi-Sánchez, Sánchez-Giménez, and Pizarro-Miranda, 2015).

That is the reason why our Twitter study focuses on reputation associated with betweenness and centrality, despite it is not always a motivating factor for political participants. "Being followed by a highly reputed user has a stronger effect in one's reputation than being followed by someone with low reputation. Thus, the simple amount of followers does not capture the recursive nature of reputation" (García et al. 2017: 2). In this regard, for Hemsley (2019), the retweet is an instrument of influence, even if it is not a definitive factor.

Jorgens, Kolleck and Saerbeck (2016) suggested using network analysis in order to overcome methodological challenges with which we are encountered with, such as the difficulty to observe influence empirically. They proposed to understand influence in relational terms, that is, depending on the relative position or specific political interactions.

In this context, think tanks' expression of influence and their presence in social media conversations has not been thoroughly researched. In order to explore such a gap in research, this paper aims to shed light on how think tanks organized their presence in Twitter, using networks in order to spread their influence among them. Our hypothesis is that a structure analysis of Twitter networks has the power to explain behavior patterns which can define think tank influence within the political environment in which they operate, and that it requires analyses which go beyond metrics such as the number of followers.

Thus, the following research question (RQ) may be formulated

- RQ1. What particular power structures do Twitter behaviors show?

- RQ2. How does the current uncertain political environment impact the influence network?

\section{THINK TANKS AND SOCIAL MEDIA INFLUENCE IN INTERNATIONAL AFFAIRS}

As already noted, think tanks produce and commit themselves to ideas, identify possible recipients for these and sell them on the basis of a policy-oriented, costbenefit analysis (Bernhagen, 2013). Influence is an inherent facet of every think tank, where "influence" is understood as the process of generating tendencies from ideas and transforming them into policy propositions for decision-makers. In order to understand organized interests and influencer dynamics, we must ask ourselves how these think tanks behave individually and in its connection to others. Twitter displays the competition/collaboration rivalry in the field of communication (Collins, DeWitt and LeFebvre, 2019).

Social media favors two types of public communication. On the one hand, general public opinion is formed on the basis of reading analyses in the press or social media. On the other, there are other better-informed actors (journalists, scholars, business schools and businesspeople, diplomats, etc.) who are influenced by the information produced by think tanks. Twitter does not se- 
parate both spheres of influence. Academic literature explores how candidates use Twitter to increase influence in "real life" (Karlsen and Enjolras, 2016), the impact in election processes (López-García and Pavía, 2019), and globally speaking, in whole political communication (Campos-Domínguez, 2017). As stated by Casero-Ripollés, "Twitter has become the nerve center of political influence" (2018: 969).

Thus, think tanks do not only seek to influence policymakers in the same way as traditional epistemic communities and legacy media in general, but now attempt to influence the media and civil society through non-governmental organizations and social movements. The topic has been developed in Abelson (2014), and recently by Tyler, Matthews and Brockhurst who considered "think tanks as knowledge-brokers" (Conley Tyler, Matthews and Brockhurst, 2017: 14). Furthermore, even if access to information has drastically improved over the past 15 years, technological resource management allows today's think tanks, as with digital media, to manage their communication strategies in order to create competitive advantages. By the same token, good communication strategies are now central to the objectives of think tanks for the purpose of gaining access to networks of political influence (Tresch and Fischer, 2015).

In order to gauge the political influence of think tanks, the variables that must be taken into account depend on the context. The academic debate is currently revolving around the complexity of analyzing qualitative variables, such as prior beliefs, information levels, and reputation, affecting the influence levels of think tanks. Networks of influence do not operate in a vacuum but reinforce the predisposition of interdependent agents to view the world according to certain value proposition. Doing so, think tanks tend to influence alike institutions in search of attention, authority or reputation. Value is created by adding institution and researcher activity: institutionalized actors, (including political parties, associations, groups) and individuals (analysts, journalists) act on Twitter as providers of relevant content.

In this regard, there is still a scarcity of research attempting to analyze and quantify think tank influence. Gotothinktank.com, a project run by the University of Pennsylvania, stands out due to the impact that it has had on the field, useful for measuring levels of political influence (Wiarda, 2015; McGann, 2019).

In this paper, we develop another type of methodology based on "fuzzy-set" techniques. In traditional logic, science offers yes/no answers for real modeled questions. However, social reality does not fit closed categories, and so new techniques are needed. As Zadeh stated, fuzzy framework "provides a natural way of dealing with problems in which the source of imprecision is the absence of sharply defined criteria of membership rather than the presence of random variables" (Zadeh, 1965: 338-353). Additionally, Zimmermann advanced that "vague conceptual phenomena can be precisely and rigorously studied" (Zimmermann, 2010: 318). Ragin (2000) stated that quantitative data, such as Twitter channels, deserves other qualitative tools based on behaviors, shared goals or particular case studies. In international communication, we found some antecedents useful for this paper (Howard and Hussain, 2013; Downey and Stanyer, 2010; GonzálezBailón, Borge-Holthoefer and Moreno, 2013). 


\section{METHODOLOGY}

An attempt was made in this paper to determine the relationships between think tanks forged through their Twitter networks, often pertaining to fields of research and political assimilation rather than to geographical location. Twitter allows us to paint a representative picture of the interests and relationships of think tanks as a defining attribute of political influence because it can illustrate the power of think tanks in relation to other agents thanks to the application of the centrality algorithm to its network, and not simply show them as isolated actors. The isolation question for us is of greater interest than the network's activity per se. In social media, most the activity is not based in the quality content, but in the capacity to influence public opinion. Here, trust is connected to biased perception. That is also the way trolls attack international public sphere: quantity denies any other rationale (Bradshaw and Howard, 2017).

To this end, a total of 695 Twitter channels encompassing the most active analysts and information centers, comprising a small but influential network in international politics and different areas of research in international relations, were chosen. The interest for the analysis is the result of different inputs and outcomes, giving a variable metrics, depending on the behavior pattern (RQ1). The influence comes from a mixed approach. Pagerank algorithm, which indicates the importance of a page based on the quantity and quality of the links directed to it; in degree/out degree in order to observe the direction of the communication flow; and betweenness centrality algorithm in order to determine the importance of a node within a network. These algorithms allow us to create a network which can indicate power in relation to other agents, and not as isolated actors. Moreover, the linkage among nodes favours clusters, which can be visually interpreted.

The 695 channels were selected in terms of their level of popularity (total number of followers) and centrality (weight in the conversation). Firstly, a snowball sampling method was used to find 100 mutually related institutions on the basis of 13 think tanks which we were previously familiar with. (Brookings Institution; Carnegie Endowment; Consejo Mexicano de Asuntos Internacionales; Consejo Argentino para las Relaciones Internacionales; Centro Brasileiro de Relaçoes Internacionais; the Elcano Royal Institute; Bruegel; the European Council on Foreign Relations (ECFR); Chatham House; the Korea Institute for International Economic Policy (KIEP); the Japan Institute of International Affairs (JIIA); the Lowy Institute for International Policy; and the South African Institute of International Affairs (SAIIA). The French and Spanish accounts were then filtered manually using a snowball method (Goodman, 1961). The lists of institutions followed by each think tank, including those related to them were then checked in order to determine their origin and main research interests. Finally, the process was repeated with the identified research centers. At the end of the processes, a sample of some 900 Twitter accounts was obtained. After filtering the unrelated accounts (e.g. media outlets or inactive accounts), a sample of 695 think-tank accounts, and those pertaining to its member researchers, was obtained for its analysis over a two-year period (2016-2017). As a result, 30,000 interactions have 
been downloaded, including tweets, retweets and replies. The tool used to complete the download was XLNode, according to the data import features developed by Hansen, Shneiderman and Smith (2010: 144).

The positioning of think-tank networks is determined by the ideas that they try to convey, regardless of their number of followers on Twitter. Additionally, a think tank's strong position within the network will guarantee that other relevant players duly recognize it. "Following" another institution implies recognition, proximity and openness, but does not necessarily mean sharing the same worldview.

The first step involved identifying a think-tank network on Twitter that served to describe the basic relationship patterns of the major international think tanks. This was achieved by limiting the sample in accordance to the methodology employed, without assessing think tank activity in various fields of research, as will be seen below. Twitter does not have the same presence in every country and the language variable is a major problem when attempting to get messages across (Leetaru et al., 2013). Chinese, Russian, and Middle Eastern think tanks tend to prefer their own language, notwithstanding the fact that this reduces their global reach. The study sample here was not restricted to English-language Twitter accounts, despite it is the lingua franca.

In view of the fact that this study is based on the structural analysis of the relationships between think tanks with an influence on Twitter, the first task consisted in dividing them into major fields of research, employing the following seven categories developed through open coding: development, energy and environment, international economy, international relations, multidisciplinary, public policy and security.

Geographical scope was created in order to specify the physical location of the target audiences of think tanks and researchers in order to understand the context in which they conduct their research and forge their political relationships. These are as follows: Europe; Latin America; Sub-Saharan Africa: Middle East and North Africa (MENA); Asia-Pacific Region; Canada; USA; and Global. Geography contributes to define the agenda, the research field and real influence, and act as connectivity predictor.

An open source network analysis and visualization software, importing UCINet and GraphML files and allowing for the collection of social media data via a set of import tools, were employed for gathering Twitter network data (Smith et al., 2009). Institutions are very choosey about who they follow, being fully aware of the relevance that they give to other players. Following someone implies opening up a communication channel that not only generates proximity and openness, but also makes it necessary to manage conversations.

After data collection, a network analysis was performed using Gephi software (Bastian, Heymann and Jacomy, 2009). The network was analyzed using variables that emphasize the in-degree - an algorithm that defines the reputation of a node within a network - over PageRank —an algorithm used in networks to determine the importance of a node within a network- due to the global nature of the former in contrast to the latter. This displays the network in terms of influence. The influence, as stated above, is centrality, in/out-degree and between- 
118 ness, not a nested structure. The centrality value of the nodes within a network plays a key role in the analysis of influence through the use of the betweenness centrality algorithm and the centrality measure in a graph based on the shortest paths. Lastly, the network was organized on the basis of its modularity (Grandjean, 2016; Fortunato, Flammini and Menczer, 2006; Freeman, 1977; Newman, 2006). Modularity analysis was resorted to here because it divides the network into modules or sub-networks based on the intensity of the bidirectional relationships -incoming and outgoing - of each institution in relation to other centers in the network.

For Newman (2006: 8582) it is possible to detect a "community structure in networks, which is framed as an optimization task in which one searches for the maximal value of the quantity known as modularity over possible divisions of a network". Therefore, modularity is understood here according to Newman (2006) as the ability of a network to be seen as a union of several modules, sub-networks, clusters or communities that interact with each other and shape a common logic within the global network. Each module has elements that differentiate it from others, while maintaining its relationship with the global network.

The color scheme shown in figure 1 was generated by applying the modularity algorithm to the influencer network. This revealed geographical patterns in the form of clusters, a surprising feature in a network generated via Twitter, where it is generally held that relationships and conversations are mainly determined by ideological and political factors.

\section{Figure 1. Think tank influencer network}

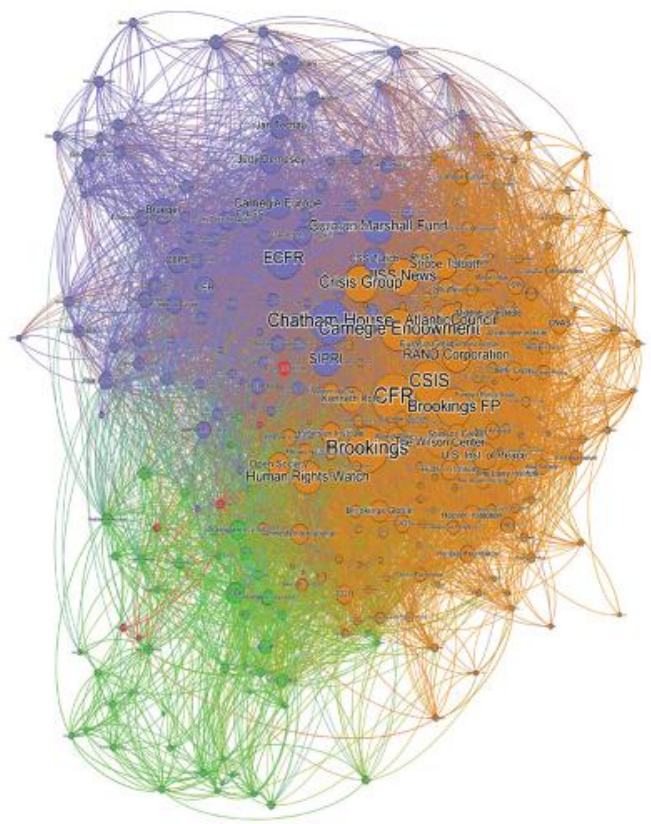

Source: own elaboration. 
In the influencer network, although the dominant language is English, there is a certain presence of Spanish, French, German and, to a lesser extent, Russian. However, there are also four clusters with a clear geographical pattern, irrespective of the language used. For Manfredi-Sánchez, Sánchez-Giménez, and Pizarro-Miranda (2015), these clusters can be interpreted as contexts of political influence generated in three political hubs: Brussels (Purple), Washington (Brown) and London (Green). The fourth sub-cluster revolves around Moscow as an emergent political hub and the fifth is a patchwork of Latin-American states that communicate mainly in Spanish, together with a mishmash of European, African, Asian and Middle Eastern actors involved in economic development and environmental issues.

\section{DATA ANALYSIS}

\section{Brussels and Washington: The Dominant Hubs}

Compared to Manfredi-Sánchez, Sánchez-Giménez, and Pizarro-Miranda (2015) dataset, Brussels hub did register a growth of 11\% and was 12\% more active than in 2015, not enough to surpass Washington as the dominant hub. Despite Europe's increased presence, neither Washington's significance nor its influence on think tanks from East Asia and the Pacific region - represented by its broad presence in the network- waned.

\section{Figure 2. The Brussels Hub}

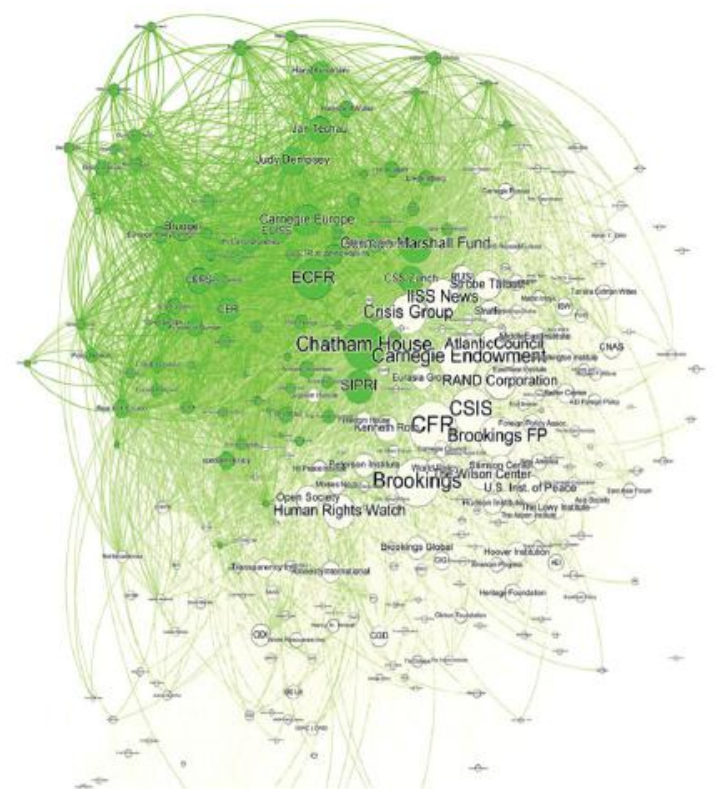

Source: own elaboration. 
When taking a comparative look at the networks generated in previous years, it can be observed that Brussels has more power of attraction than London in the influencer network analyzed here, as represented by its yearly growth, while the British cluster has lost ground to its European counterpart. Even though many British think tanks have acquired European elements - that is, issues related to the European Union in one way or another-, this does not necessarily mean that they are becoming more European. Rather, they are establishing more connections with continental sub-networks, while their analysts are fostering relationships with European environments. This could very well be in anticipation of post-Brexit Europe, where London had more power in the European Union (EU) as a second nexus. Now, with the prospect of leaving the EU, think tanks have had to divide their time between London and Brussels, the latter gaining network influence at the expense of the former.

\section{Figure 3. The British Network by main research fields}

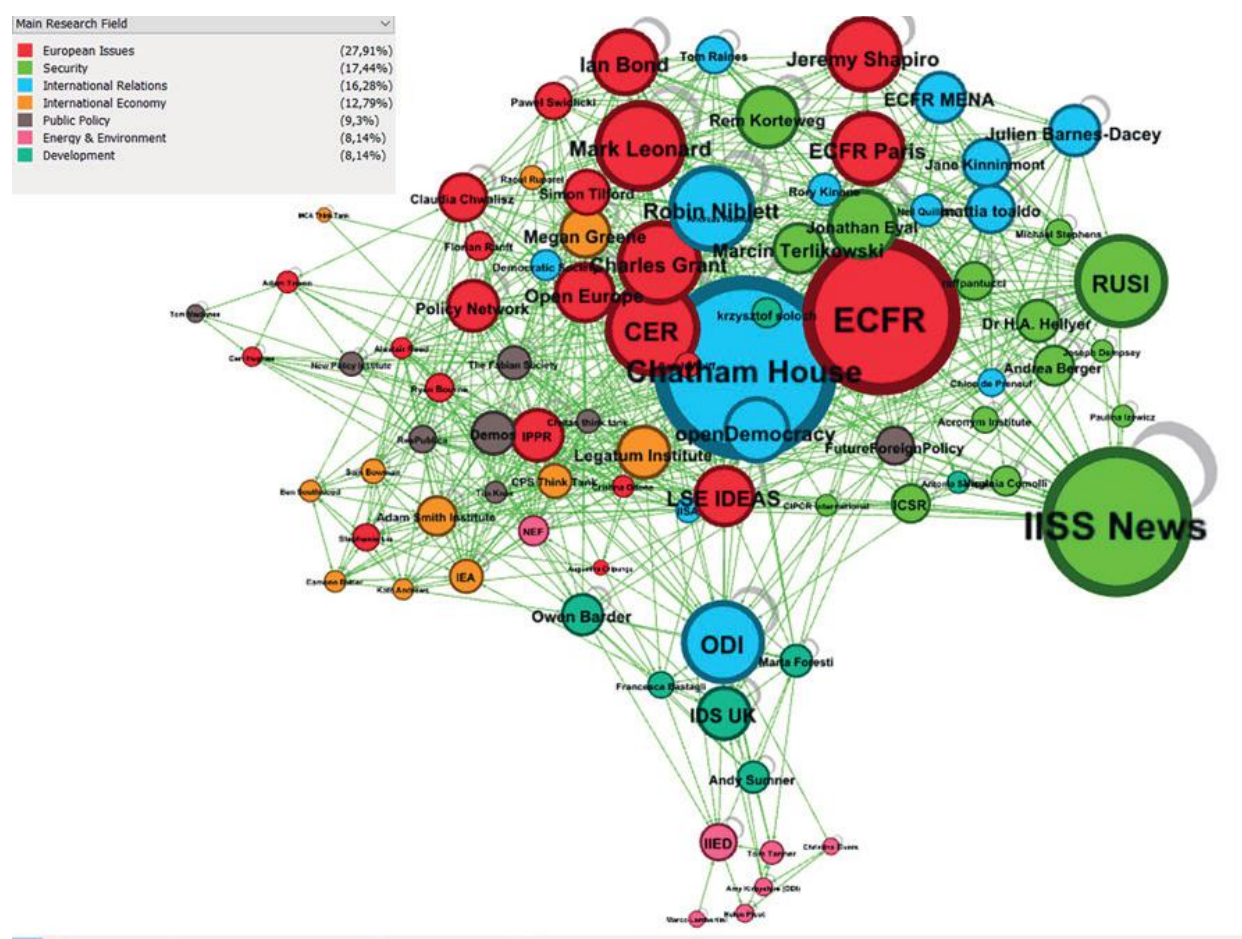

Source: own elaboration.

In light of the indexation of the fields of research in the study database of think tanks and independent analysts, it can be observed that London's interests as a political hub lie in security, international relations and European issues, thus converting this hub into a channel for the flow of ideas between Europe, the USA and some parts of Latin America. 
Figure 4. UK Think Tanks and the four main nexuses of influence

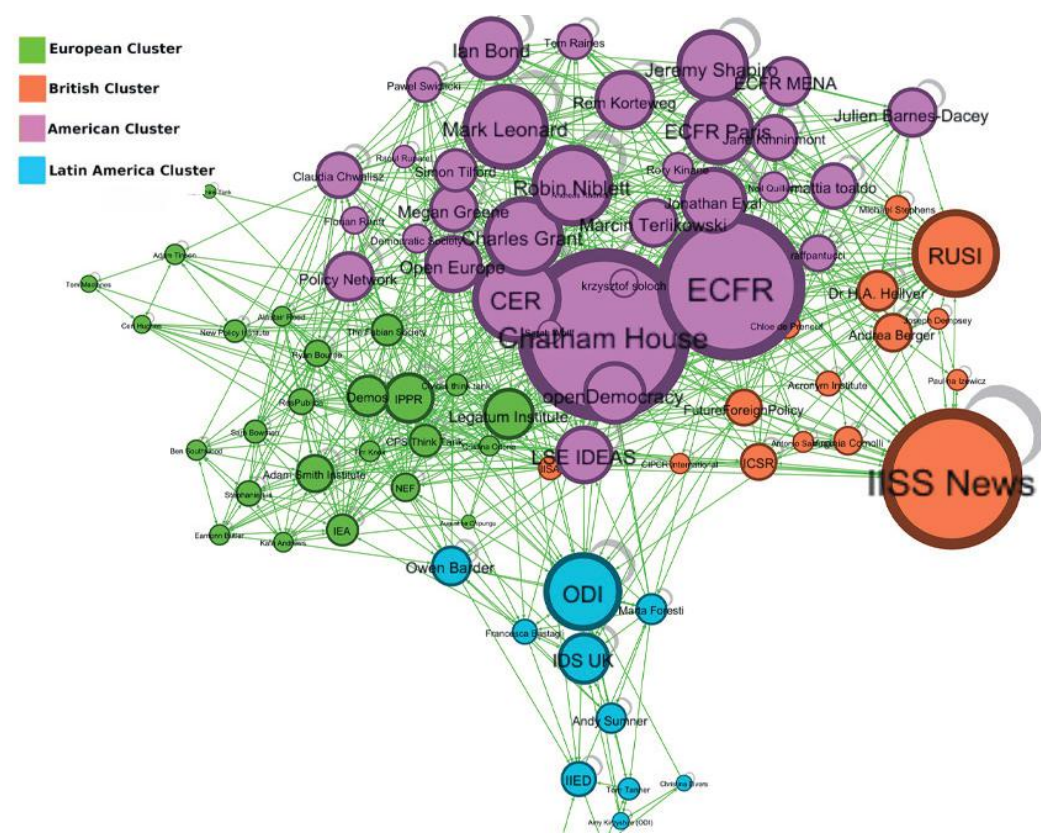

This nexus is evidently becoming weaker and, consequently, many thinks tanks are starting to strengthen their ties with other hubs such as Brussels or the socalled "Latin-American cluster", possibly due to the new political context emerging in the wake of the Brexit referendum and the ongoing negotiations between the EU and the United Kingdom (UK). If we compare the networks created from the relationships of two European think tanks such as Bruegel and IFRI (Institut Français des Relations Internationals) with two British think tanks, Chatham House and ECFR, we can see that the networks of the British think tanks are more global, independently of their research interests. It is necessary to point out that even though ECFT is a British think tank, their analyses are about European issues. The global tendency is that influence relationships between Europeans and North Americans tend to be structured through London.

As we can observe in figure 3, The British cluster has become more institutionalized in relation to fields of research, specializing in European issues with a focus on economics. In any case, London still prevails as the main nexus of influence with respect to global topics such as development, climate change policy and economic globalization. At the same time, rather than waning, part of the London hub, such as ECFR, seems to be looking towards Europe not so much to exert political influence over an increasingly more polarized European network, as to understand the different perspectives on Brexit and the future of the EU. While think tanks are generally open spaces for mediation, hubs (such as London) can specialize. Brexit breaks the homogeneity of the British hub. On the 
122 one hand, data shows that the British hub tends to become more European due to high centrality of its think tanks dedicated to European issues. On the other hand, the presence of international themes related to economy, security and international relations keeps its weight, but adopts a more peripheral role. It is possible that Brexit is the cause of this emergent polarization.

\section{Figure 5. Network comparison}

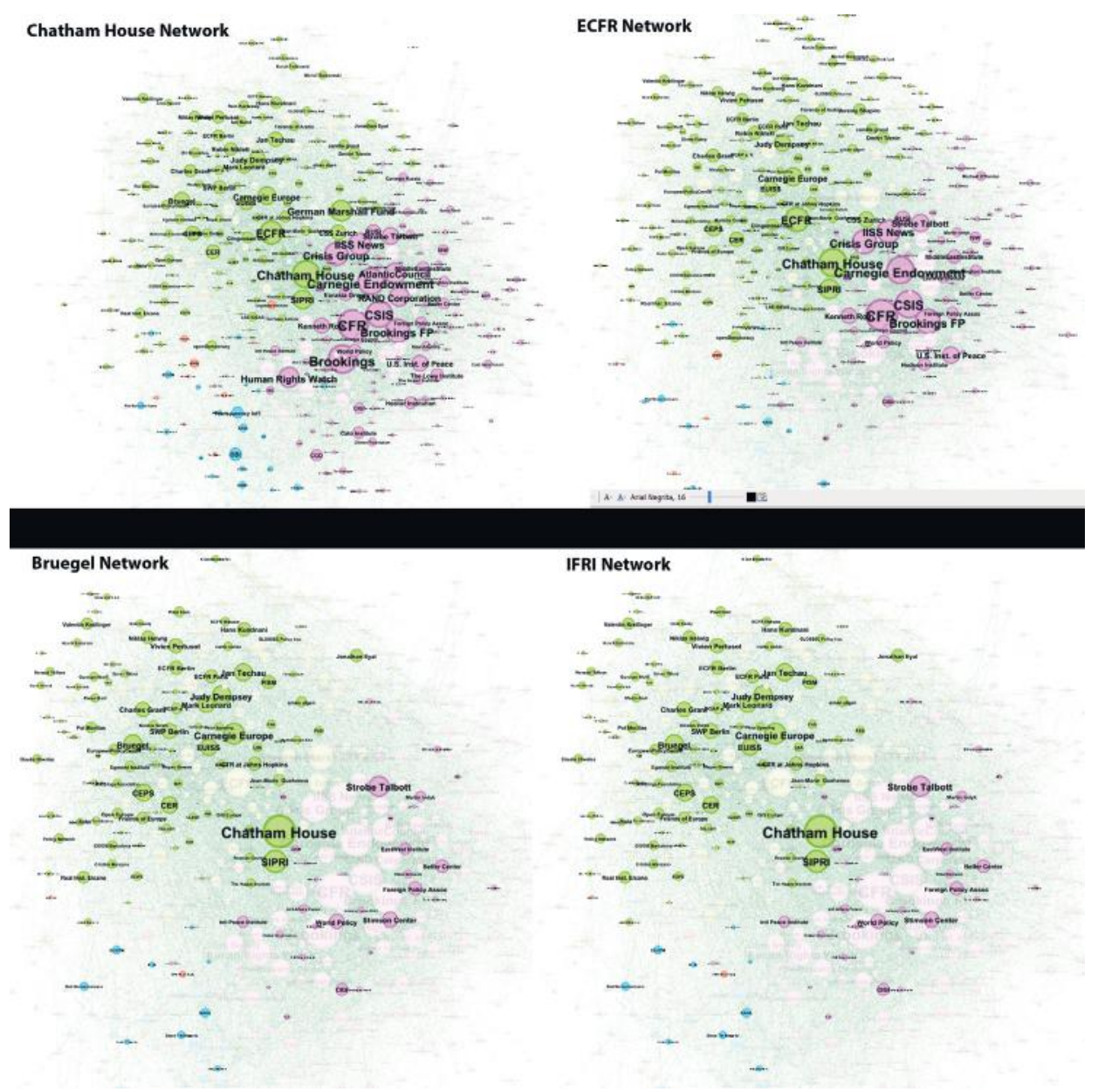

Source: own elaboration.

The size of the North-American cluster, which revolves around Washington and specializes in global security issues, is apparently decreasing possibly due to the indifference of the Trump administration to influencer networks, as observed in the US public diplomacy network on Twitter (Sánchez-Giménez and Tchubykalo, 2018). The North-American cluster includes some British, Turkish, Australian, Canadian and European think tanks dedicated to the analysis of global secu- 
rity and geopolitics. Despite being a network that is mainly characterized by standard topics in international relations studies, such as security and foreign policy, it also includes some think tanks relating to public policy and local politics. As can be observed in figure 5, the grey dots represent President Trump's Twitter channels: @potus and @TheRealDonaldTrump. His election victory and particular vision of what has been previously described as a new form of public diplomacy, has been met with a certain degree of indifference by the participants in the influencer network analyzed here shown by the size of the node @realDonaldTrump which corresponds to the US President's private Twitter account. These presidential Twitter channels are disassociating themselves from the rest of the network, illustrated by the asymmetric relationships between Donald Trump and traditional influencers, which has reduced its interactions with the de facto powers in Washington. This phenomenon is regarded here as a breaking episode because it discontinues with traditional standards. Firstly, it does not create dialogue and interaction spaces, represented by the lack of mentions from Donald Trump's account; secondly, it monopolizes conversations instead of allowing other relevant institutions to get a look in because it does follow any think tanks from within our network; and finally, the tone of conversations is, by and large, undiplomatic and unfriendly. With this behavior, we propose that the Trump administration has apparently refrained from endorsing any type of political influence originating from external actors, at least for the time being.

\section{Figure 6. President Trump, POTUS and the North American think tanks}

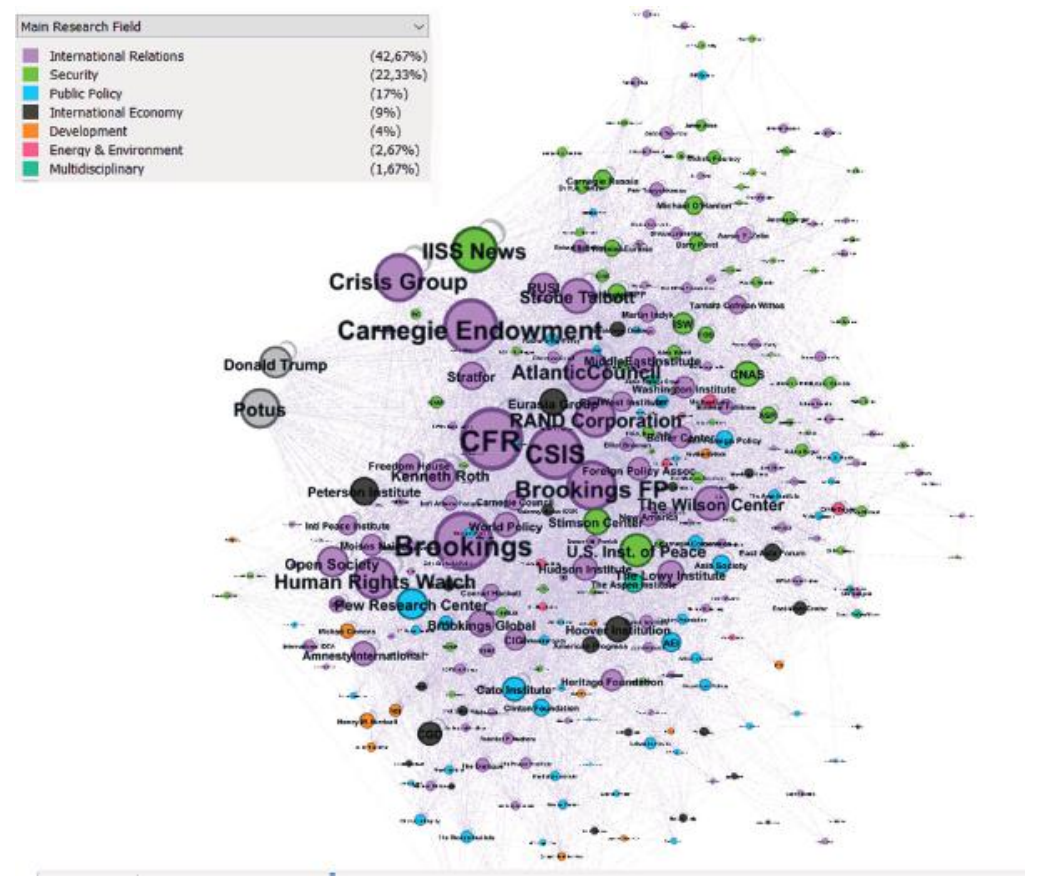


124 The so-called "Latin-American cluster" has switched its focus and grown due to the increase in network modularity. It can be inferred that the interest in Latin American issues is increasing, but, on the other hand, these issues are diffused in a sub-network in which the Spanish language and Latin American concerns have lost ground to global issues and international economics.

\section{Influence ACCORding to Moscow}

The fledgling Russian cluster mainly communicates in Russian and works with areas pertaining to Russian public policy. These think tanks attempt to engage two audiences. Firstly, the domestic Russian-speaking audience among whom articles for or against President Putin's policies are disseminated. Secondly, a foreign non-Russian speaking audience looking for English content. Accordingly, Russian think tanks are divided into different sub-clusters, which reduce their influence since the Russian language has little impact in the international sphere. While Russian think tanks and analysts previously had strong connections with the European network, the general picture in 2017 suggests that Moscow intends to isolate itself in order to protect its policy discussions from foreign influence.

\section{Figure 7. The Moscow Network}

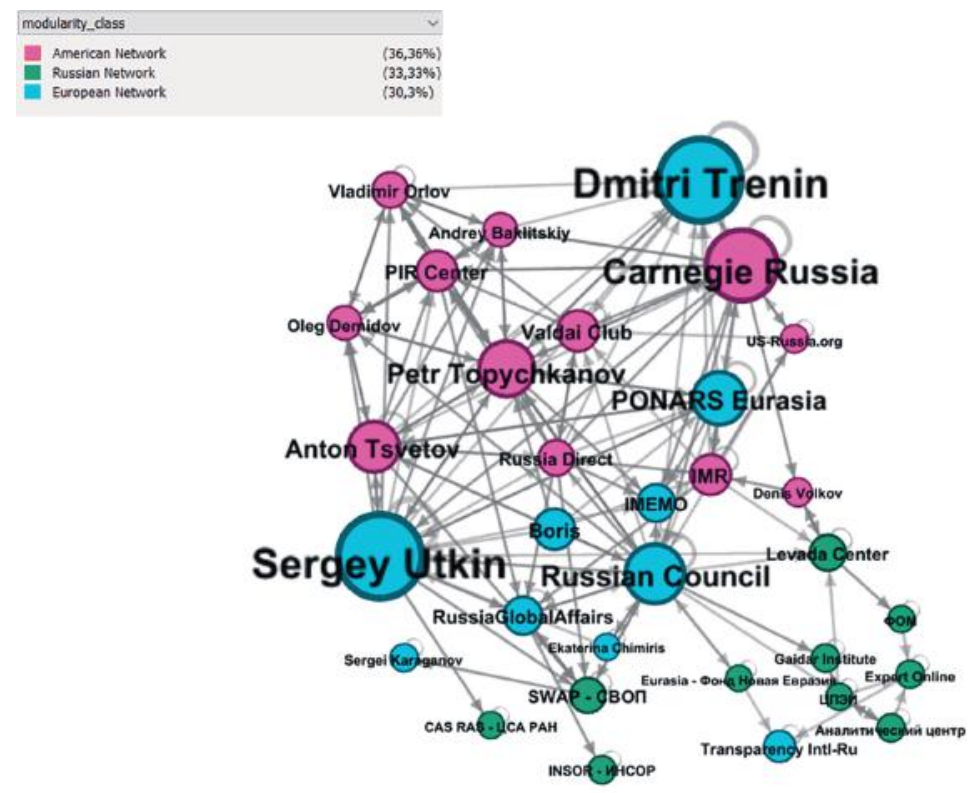

Source: own elaboration.

Primarily, in regard to 2016-2017 analysis, it can be seen that some Russian think tanks had considerably reduced, and in some cases ceased, their Twitter activity over the years, while still maintaining their relationship networks through external mentions and follower numbers, with an impact on their in-degree. Several 
important nodes such as CPEI and form media had completely curtailed their networking activities in late 2015 and early 2016. Furthermore, it can be observed that all the nodes in the Russian cluster are think tanks or institutions, rather than individual journalists or researchers, while at least $50 \%$ of the nodes in the European cluster are individual, non-institutional accounts. It seems therefore, that there is some political influence on what sort of information is generated officially through Russian information centers, while individual journalists are able to maintain some degree of independence in the network. Additionally, it is important to note that only one third of the Russian nodes have been grouped into what has been identified here as the Russian cluster according to its modularity factor, with the other two thirds spread evenly between the European and North American clusters.

Figure 8. "Petition in change.org to remove Levada Centre, an influential Russian think-tank founded in 1988 and that prides itself on its Western-educated academics, from the list of foreign agents"

\section{Исключите Левада-центр из списка иноагентов!}
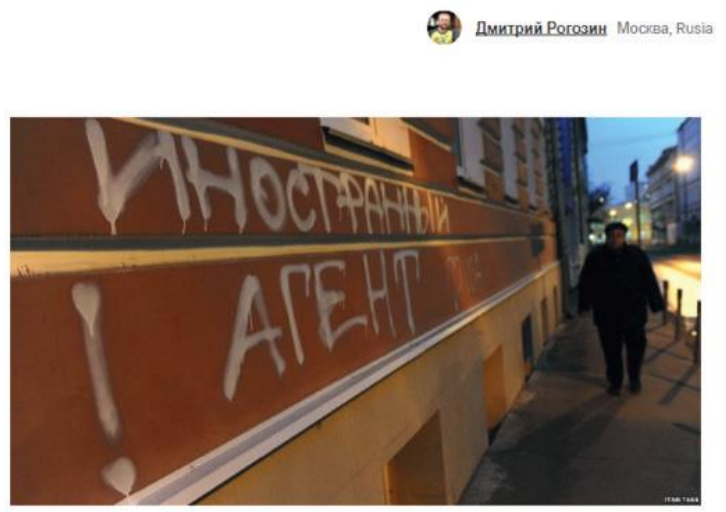

5 сентября Минюст включил ведущий независимый исследовательский центр Левада в реестр иностранных агентов.

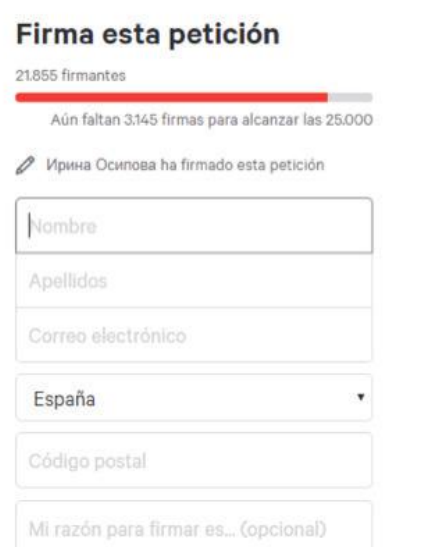

Source: <https://www.change.org/>

In 2016, for example, out of 165 European nodes, 20 were of Russian origin, while the following year this number had dropped to 10 out of 238 European nodes. This goes to show that the nodes in the new Russian cluster, according to the network's modularity factor, are gradually distancing themselves from the European and North-American sub-networks (figure 7). The Russian Council -a think tank specializing in geopolitics - is found to be the main, and almost only, intermediary between think tanks belonging to the Russian cluster and the rest of the world; with Sergey Utkin being the main Russian influencer despite forming part of the European cluster. 
Russian think tanks basically address topics such as Trump, international relations, military concerns and geopolitics. For their part, those in the European cluster focus more on EU politics (such as recent elections in EU Member States) from an international relations perspective, while those in the North American cluster give priority to issues pertaining to Russia-US relations. The key particularity of the Twitter accounts of think tanks in the Russian cluster seems to be their propensity to produce articles about the foreign influence on Russia from a geopolitical and economic perspective. Publications in Russian, governmental pressure on alleged foreign agents and the difference in the topics covered by the Russian nodes both inside and outside the Russian cluster appear to have been important factors in strengthening the relationship between them and weakening their links to the rest of the network.

\section{CONCLUSIONS}

The data provided results enable to answer the research questions, and to discuss two topics related to the theoretical framework.

Regarding RQ1, our data indicates a semiopen structure, where authority is dispersed. 695 accounts involve interactions between separate areas of research. That is a large number of actors, delimited in terms of their reach and geographical scope. The semiopen patterns of behaviour indicate that influence depends on areas of interest, not in number of followers. In the 2016-2017 period, think tanks organize themselves in hubs, relying on other similar actors their influence with similar or specific interests.

Since political influence is best exercised through a network (Slaugther, 2017), we consider it more appropriate to map relationships in which ideas are channeled towards their target audiences and positioned via the network. For this purpose, there is a need to understand the existing relationships among the think tanks themselves and between these and the three most important international political hubs (Washington, London and Brussels), including the goals and interests of policymakers in each one of them. Russian and Chinese think tank reduces their participation in global conversation, as they refuse to disseminate English contents or translations in their Twitter accounts.

In the analyzed period, social media operationalize the change in power, because think tanks use social networks, particularly Twitter, to reach new and former audiences. The business is the same, i.e., to influence public opinion, policy makers, and journalists, but Twitter sophisticates communication. Having influence in social media, in terms of value of nodes, does not mean having more followers, but centrality, in-degree and out-degree positions in the network. The more central the position, the more influence in policy making in international affairs.

Our second RQ tried to evaluate the effects of the uncertainty of the 2016 political events within think tank behaviour throughout a year of global change. In 2017, political phenomena such as Brexit, the Trump administration and the latest Russian political developments produced changes in the global influencer 
network analyzed here. Brexit has placed the spotlight on Brussels insofar as everyone looks to the hub to understand such a complex political process. On its end, the Trump administration has hitherto ignored the conventional channels employed previously for enhancing political influence. Meanwhile, the Moscow cluster has implemented policies with the intention of isolating itself from foreign influence. It should be noted that due to the geographical differences in Twitter use (such as its prohibition in China or the use of non-English languages), no meaningful political Asian hub has been identified in the network. This would suggest that Asian think tanks are not competing in the global sphere of influence to the same extent as their American and European counterparts. That isolation is consistent with Russian desire to operate in an excluding environment. These circumstances have led to the network's polarization, as political interests in Washington, London and Moscow has become more localized, concentrating more on public policy. Furthermore, the network is a lot simpler now due to the fact that the clusters establish fewer external relationships and more internal ones. The size and influence of the clusters also varies, with that of Brussels growing at the expense of those of Washington and London. Moreover, Brexit in the UK and the Trump administration's new barriers to free trade have caused unrest among traditional influencer networks, thereby producing shifts in their relationships; Trump, Brexit and Russian isolationist policies are fostering the growth of the European network since their primary focus on domestic issues has reduced their own global influence. The Brussels cluster, for its part, is deemed to be the most stable, as it seems to be maintaining the status quo in this regard. To conclude, as Brussels has consolidated its position in the global influencer network, the after Brexit years might very well have been the year in which Europe had the opportunity take the lead in many aspects of global political activity, such as climate change, support for democratization processes, human rights and international trade. These topics correspond to normative power in the EU, which is where its true influence lies.

To follow up, the transformation of influence is not a univocal idea, but polysemic. Using network analysis, we can find different behaviors in the use of social networks. Twitter appears as a global interaction mechanism, which in practice operates in regional hubs. In future research, it is considered how Twitter transforms its influence into concrete decisions, linked to decision-making. Doing so, we can discuss some theoretical basis of influence, knowledge regime and political imagination capture. As far as Twitter opens a new era of geopolitical communication, future avenues for research include how position papers and other legacy techniques will become irrelevant to press policy questions. When imitating social media activism, will future think tanks produce better documents and scholars? 
Evgeni Tchubykalo (etchubykalo@gmail. com) is a doctoral researcher from the Communication and Media Research Institute (CAMRI), University of Westminster, London. He specializes is critical discourse analysis and is writing a dissertation about collaborative knowledge creation on contentious Wikipe-

Juan Luis Manfredi-Sánchez (Juan.Manfredi@uclm.es) is a full professor of Journalism and International Studies at the Universidad de Castilla-La Mancha. He is the author of more than 30 academic articles and writes about international relations and diplomacy,

Juan Antonio Sánchez-Giménez (jasanchez@ rielcano.org) is Head of the Information Service and Data Analysis at the Elcano Royal Institute. He is a senior professional of information and scholarly communication on international relations and specialist in open source information tools (Open Source Intelligence). BA in Arabic Studies and Islam from the Universidad Autó- dia articles about armed conflicts. BA in $\mathrm{Mu}$ sical Teaching by the Universitat Autònoma de Barcelona, he also graduated from an MA in Intercultural Education from the University of Oulu, Finland, and an MA in Pedagogy from the Universidad Complutense de Madrid (UCM), Spain.

communication and technology, as well as political risk and liberal order. He is a member of the Scientific Council of the Elcano Royal Institute and the editorial board of Esglobal. com, a leading journal of international journalism in Spanish.

noma de Madrid (UAM), he also has graduate degrees in International Studies, Mediterranean and the Arab World (UAM), and MA in European Union at the Instituto Universitario Ortega y Gasset and MA in International Relations at the Universidad Carlos III de Madrid, and MA in Information and Library Science at the Universidad Complutense de Madrid (UCM).

\section{References}

Abelson, D. E. (1992). "A New Channel of Influence: American Think Tanks and the Media". Queen's Quarterly, 99(4), p. 849.

-. (2002). Do Think Tanks Matter?: Assessing the Impact of Public Policy Institutes. Montreal: McGill-Queen's Press.

—. (2014). "Old World, New World: The Evolution and Influence of Foreign Affairs Think-Tanks". International Affairs, 90(1), pp. 125-142. DOI: <10.1111/1468-2346.12099>.

Ahmad, M. (2008). "US Think Tanks and the Politics of Expertise: Role, Value and Impact". Political Quarterly, 79(4), pp. 529-555. DOI: <10.1111/j.1467-923X.2008.00964.X>.
Álvarez-Rivadulla, M. J.; John Markoff, J. and Montecinos, V. (2010). "The TransAmerican Market Advocacy Think Tank Movement". In: A. Garcé and G. Uña, Think Tanks and Public Policies. Buenos Aires: Fundación CIPPEC: Fundación Siena Investigación Aplicada de Políticas Públicas, pp. 172-199.

Anstead, N. and Chadwick, A. (2018). “A Primary Definer Online: The Construction and Propagation of a Think Tank's Authority on Social Media". Media, Culture and Society, 40(2), pp. 246-266. DOI: $<10.1177 / 0163443717707341>$. 
Arin, K. Y. (2014). Think Tanks: The Brain Trusts of US Foreign Policy. Gräfelfing, Germany: Springer VS. DOI: $<10.1007 / 978-3-658-$ 02935-7>.

Baier, G. and Bakvis, H. (2001). "Think Tanks and Political Parties: Competitors or Collaborators?". ISUMA, Canadian Journal of Policy Research, 2(1), pp. 107-113.

Bastian, M.; Heymann, S. and Jacomy, M. (2009). "Gephi: An Open Source Software for Exploring and Manipulating Networks". Third International AAAI Conference on Weblogs and Social Media. San Jose. California: Association for the Advancement of Artificial Intelligence (AAAI), pp. 361-362. DOI: <10.1136/ qshc.2004.010033>.

Bernhagen, P. (2013). "When do Politicians Listen to Lobbyists (and Who Benefits when They Do)?". European Journal of Political Research, 52(1), pp. 20-43. DOI: <10.1111/ j.1475-6765.2012.02062.x>.

Bradshaw, S. and Howard, P. N. (2017). “Troops, Trolls and Troublemakers: A Global Inventory of Organized Social Media Manipulation". Working Paper, 12. Oxford (UK). Available at: <https://comprop.oii.ox.ac. uk/wp-content/uploads/sites/89/2017/07/ Troops-Trolls-and-Troublemakers.pdf $>$.

Campbell, J. L. and Pedersen, O. K. (2014). The National Origins of Policy Ideas: Knowledge Regimes in the United States, France, Germany, and Denmark. Princeton NJ and Oxford UK: Princeton University Press.

Campos-Domínguez, E. (2017). "Twitter y la comunicación política". El Profesional de la Información, 26(5), pp. 785-793. DOI: $<10.3145$ /epi.2017.sep.01>.

Casero-Ripollés, A. (2018). "Research on Political Information and Social Media: Key Points and Challenges for the Future". El Profesional de la Información, 27(5), pp. 964-974. DOI: <10.3145/epi.2018.sep.01>

Castillo, A. and Trujillo, B. (2012). "Los 'think tanks' en Estados Unidos. Análisis de sus temáticas, actividades y estrategias comu- nicativas". In: E. Ordeix i Rigo and J. A. Rom Rodríguez (eds.), La innovació en relacions públiques. Barcelona: Trípodos, pp. 147-162.

Chafuen, A. (2019). "The 2019 Ranking of Free-Market Think Tanks Measured By Social Media Impact". Forbes, 10 April. Available at: <https://www.forbes.com/sites/ alejandrochafuen/2019/04/10/the-2019ranking-of-free-market-think-tanks-measuredby-social-media-impact/>.

Collins, S. D.; DeWitt, J. R. and LeFebvre, R. K. (2019). "Hashtag Diplomacy: Twitter as a Tool for Engaging in Public Diplomacy and Promoting US Foreign Policy". Place Branding and Public Diplomacy, 15(2), pp. 78-96. DOI: $<10.1057 /$ s41254-019-00119-5>.

Conley-Tyler, M.; Matthews, R. and Brockhurst, E. (2019). "Think Tank Diplomacy". Brill Research Perspectives in Diplomacy and Foreign Policy, 2(3), pp. 1-96. DOI: $<10.1163 / 24056006-12340007>$.

Diez, Th. (2013) "Normative Power As Hegemony". Cooperation and Conflict, 48(2), pp. 194-210. DOI: <10.1177/0010836713485 387>.

Downey, J. and Stanyer, J. (2010). "Comparative Media Analysis: Why Some Fuzzy Thinking Might Help. Applying Fuzzy Set Qualitative Comparative Analysis to the Personalization of Mediated Political Communication". European Journal of Communication, 25(4), pp. 331-347. DOI: $<10.1177 / 0267323110384256>$.

Drezner D. W. (2017). The Ideas Industry. New York, NY: Oxford University Press.

Fortunato, S.; Flammini, A. and Menczer, F. (2006) "Scale-Free Network Growth by Ranking". Physical Review Letters, 96(21). DOI: $<10.1103 /$ PhysRevLett.96.218701>.

Freeman, L. C. (1977). "A Set of Measures of Centrality Based on Betweenness". Sociometry, 40(1), pp. 35-41. DOI: <10.2307/3033543>.

Garcia, D.; Mavrodiev, P.; Casati, D.; Schweitzer, F. (2017). "Understanding Popularity, Reputation, and Social Influence in 
the Twitter Society". Policy and Internet, 9(3), pp. 343-364. DOI: <10.1002/poi3.151>.

González-Bailón, S.; Borge-Holthoefer, J. and Moreno, Y. (2013). "Broadcasters and Hidden Influentials in Online Protest Diffusion". American Behavioral Scientist, 57(7), pp. 943-965. DOI: <10.1177/0002764213479 371>.

Goodman, L. A. (1961). "Snowball Sampling". The Annals of Mathematical Statistics, 32(1), pp. 148-170. DOI: <10.1214/ aoms/1177705148>.

Grandjean, M. (2016). “A Social Network Analysis of Twitter: Mapping the Digital Humanities Community". Cogent Arts \& Humanities. Edited by A. Mauro. Cogent OA, 3(1), p. 1-14. DOI: <10.1080/23311983.2016.1171 $458>$.

Haas, P. M. (1992). "Introduction: Epistemic Communities and International Policy Coordination, International Organization". International Organization, 46 (1), pp. 1-35. DOI: $<10.1017 /$ S0020818300001442>.

Hansen, D. L., Shneiderman, B. and Smith, M. A. (2010). Analyzing Social Media Networks with NodeXL: Insights from a Connected World. Amsterdam, Boston, London: Morgan Kaufman.

Hemsley, J. (2019). "Followers Retweet! The Influence of Middle-Level Gatekeepers on the Spread of Political Information on Twitter". Policy and Internet, 9999(9999), pp. 1-25. DOI: <10.1002/poi3.202>.

Howard, P. N. and Hussain, M. M. (2013). Democracy's Fourth Wave? Oxford, UK and New York: Oxford University Press. Available at: <https://deepblue.lib.umich. edu/bitstream/handle/2027.42/117564/ De mocracy \% $27 \mathrm{~s}+\mathrm{F}$ our th $+\mathrm{W}$ ave . pdf? sequence $=1>$.

Joergens, H.; Kolleck, N. and Saerbeck, B. (2016) "Exploring the Hidden Influence of International Treaty Secretariats: Using Social Network Analysis to Analyse the Twitter Debate on the 'Lima Work Programme on Gender'". Journal Of European Public Policy, 23(7,
SI), pp. 979-998. DOI: <10.1080/13501763.20 16.1162836>.

Karlsen, R. and Enjolras, B. (2016). "Styles of Social Media Campaigning and Influence in a Hybrid Political Communication System: Linking Candidate Survey Data with Twitter Data". International Journal of Press/Politics, 21(3), pp. 338-357. DOI: $<10.1177 / 1940161216645335>$.

Leetaru, K.; Wang, S.; Padmanabhan, A. and Shook, E. (2013). "Mapping the Global Twitter Heartbeat: The Geography of Twitter". First Monday, 18(5-6). DOI: <10.5210/ fm.v18i5.4366>.

Lewis, J. and Cushion, S. (2017). "Think Tanks, Television News and Impartiality". Journalism Studies, 20(4), pp. 480-499. DOI: $<10.1080 / 1461670 x .2017 .1389295>$.

López-García, G. and Pavía, J. M. (2019). "Political Communication in Election Processes: An Overview". Contemporary Social Science, 14(1), pp. 1-13. DOI: <10.1080/21582041. 2018.1479040>.

Manfredi-Sánchez, J. L.; Sánchez-Giménez, J. A. and Pizarro-Miranda, J. (2015). "Structural Analysis to Measure the Influence of Think Tanks' Networks in the Digital Era". The Hague Journal of Diplomacy, 10, pp. 363-395. DOI: <10.1163/1871191X12341320>.

McDonald, L. (2014). "Think Tanks and the Media: How the Conservative Movement Gained Entry Into the Education Policy Arena". Educational Policy, 28(6), pp. 845-880. DOI: <10.1177/0895904813492372>.

McGann, J. G. and Weaver, R. K. (2000). Think Tanks and Civil Societies: Catalysts for Ideas and Action. New York, NY: Routledge. DOI: $<10.4324 / 9781315135595>$.

McGann, J. G. and Johnson, E. C. (2005). Comparative Think Tanks, Politics and Public Policy. Cheltenham. UK: Edward Elgar.

McGann, J. G. (2019). "2018 Global Go To Think Tank Index Report". Available at: <https://repository.upenn.edu/cgi/ 
viewcontent.cgi article $=1017 \&$ context $=$ think_tanks $>$.

Medvetz, T. (2008). "Think Tanks as an Emergent field, Social Science Research Council". Available at: <http://sociology.ucsd.edu/ faculty/bio/documents/Medvetz.08.SSRC.pdf>.

-. (2012). Think Tanks in America. Chicago: University of Chicago Press.

Newman, M. E. J. (2006) "Modularity and Community Structure in Networks". Proceedings of the National Academy of Sciences, 103(23), pp. 8577-8582. DOI: <10.1073/ pnas.0601602103>.

Ragin, C. C. (2000). NoFuzzy-Set Social Science. Berkeley: Los Angeles: London: University of Chicago Press.

Rich, A. and Weaver, R. K. (2000). "Think Tanks and US Media". Harvard International Journal of Press/Politics, 5(4), pp. 81-103. DOI: $<10.1177 / 1081180 X 00005004006>$.

Rich, A. (2004). Think Tanks, Public Poli$c y$, and the Politics of Expertise. Cambridge UK: Cambridge University Press.

Sánchez-Giménez, J. A. and Tchubykalo, E. (2018). "Donald Trump's Twitter Account: A Brief Content Analysis". Revista Elcano, 23, pp. 107-117.

Slaughter, A. M. (2017). The Chessboard and the Web: Strategies of Connection in a Networked World. New Haven (USA) and London (UK): Yale University Press.

Smith, M. A.; Shneiderman, B.; MilicFrayling, N.; Mendes-Rodrigues, E.; Barash, V.; Dunne, C.; Capone, T.; Perer, A. and Gleave, E. (2009). "Analyzing (Social Media) Networks with NodeXL". Proceedings of the Fourth International Conference on Communi- ties and Technologies - C\&T '09, p. 255. DOI: $<10.1145 / 1556460.1556497>$.

Stone, D. (1996). Capturing the Political Imagination: Think Tanks and Public Policy. London: Frank Cass.

Tresch, A. and Fischer, M. (2015). "In Search of Political Influence: Outside Lobbying Behaviour and Media Coverage of Social Movements, Interest Groups and Political Parties in six Western European Countries". International Political Science Review, 36(4), pp. 355 372. DOI: <10.1177/0192512113505627>.

Wallace, W. (1994). "Between Two Worlds: Think-Tanks and Foreign Policy". In: Hill, C. and Beshoff, P. (eds.). Two Worlds of International Relations: Academics, Practitioners and the Trade in Ideas. London; New York: Routledge; London School of Economics, pp. 137-161.

Weaver, R. K. (1989). "The Changing World of Think Tanks". PS: Political Science and Politics, 22(3), pp. 563-578. DOI: $<10.2307 / 419623>$.

Wiarda, H. J. (2015). "Think Tanks and Foreign Policy in a Globalized World: New Ideas, New 'Tanks', New Directions". International Journal: Canada's Journal of Global Policy Analysis, 70(4), pp. 517-525. DOI: $<10.1177 / 0020702015591760>$.

Xifra, J. and Ponsa, F. (2009). El marketing de las ideas. Barcelona: UOC.

Zadeh, L. A. (1965). "Fuzzy Sets". Information and Control, 8(3), pp. 338-353. DOI: $<10.1016 /$ s0019-9958(65)90241-X>.

Zimmermann, H.-J. (2010) "Fuzzy Set Theory Review 2010". Wiley Interdisciplinary Reviews: Computational Statistics. DOI: $<10.1002 /$ wics.82>. 